\title{
Peningkatan Hasil Belajar Siswa melalui Metode Inkuiri di MIS Gampong Mutia
}

\author{
Rina Purnama Sari \\ Fakultas Keguruan dan Ilmu Pendidikan, Universitas Sains Cut Nyak Dhien, Langsa \\ rinapurnamasari457@gmail.com
}

\begin{abstract}
The activeness of students in learning is of course very necessary because by activating their five senses, they will learn more meaningfully. One of the teaching methods that can activate students' five senses is the inquiry method. The purpose of this study was to describe the increase in science learning outcomes at MIS Gampong Mutia. The design of this study used a control group posttest design. The instrument used is a test of learning outcomes for the material structure and function of plant parts. The results showed that there was an increase in science learning outcomes in classes that applied the inquiry method. So it can be said that this guided inquiry method is appropriate for use on the material structure and function of plant parts.
\end{abstract}

Keywords: Methods, Learning Outcomes, Inquiry, Students.

\begin{abstract}
Abstrak
Keaktifan siswa dalam belajar tentunya sangat diperlukan karena dengan mengaktifkan panca inderanya, maka mereka akan belajar akan lebih bermakna. Salah satu metode pengajaran yang dapat mengaktifkan panca indera siswa adalah metode inkuiri. Tujuan penelitian ini adalah mendeskripsikan peningkatan hasil belajar IPA di MIS Gampong Mutia. Desain penelitian ini menggunakan control group postest design. Instrumen yang digunakan adalah tes hasil belajar untuk materi struktur dan fungsi bagian tumbuhan. Hasil penelitian menunjukkan bahwa ada peningkatan hasil belajar IPA pada kelas yang menerapkan metode inkuiri. Sehingga dapat dikatakan bahwa, metode inkuiri terbimbing ini tepat digunakan pada materi struktur dan fungsi bagian tumbuhan.
\end{abstract}

Kata kunci: Metode, Hasil Belajar, Inkuiri, Siswa. 


\section{A. Pendahuluan}

Ilmu Pengetahuan Alam (IPA) berhubungan dengan proses mencari tahu mengenai fenomena alam yang dilakukan secara prosedural, sistematis, dan ilmiah bukan sekadar kumpulan pengetahuan saja namun juga pengalaman langsung bagi peserta didik untuk mengembangkan kompetensinya (Fitriani, 2010). Untuk itu perlu diperhatikan metode pembelajaran yang tepat, sehingga proses belajar mengajar berjalan secara efektif, tidak monoton.

Banyak sekali metode pengajaran yang mampu mengaktifkan siswa dalam belajar, oleh karenanya guru perlu memiliki kemampuan dalam mengenali karakteristik metode pengajaran yang kira-kira tepat untuk diterapkan dan sesuai dengan karakteristik siswa di kelasnya. Seperti halnya dengan MIS Gampong Mutia, proses pembelajaran sudah berjalan dengan baik, namun masih perlu peningkatan pada beberapa hal, salah satunya adalah pada inovasi pembelajaran yang mampu merangsang siswa untuk terlibat aktif selama proses belajar mengajar.

Permasalahan dalam proses belajar mengajar saat ini di MIS Gampong Mutia masih menggunakan metode lama yang berupa ceramah sehingga sulit meningkatkan pencapaian kualifikasi dan klasifikasi nilai. Sebagaimana yang terjadi di kelas VI MIS Gampong Mutia, di mana hasil belajar siswa pada mata pelajaran IPA merupakan urutan yang ketiga terbawah dari semua mata pelajaran yang diajarkan di kelas IV. Menurut hasil analisis ulangan harian, diketahui bahwa hasil belajar IPA siswa baru mencapai rata-rata kelas 5,6 dan pada ulangan kedua meningkat menjadi 5,9. Tentunya angka tersebut masih berada di bawah standar KKM yakni 70.

Fenomena yang terlihat di kelas juga menampakkan bahwa siswa kurang bergairah dalam belajar IPA, siswa sibuk melakukan aktivitas lain seperti mencoretcoret di meja atau di buku lain, ada juga yang berbicara dengan temannya, bahkan ada yang terlihat menjahili teman sebangkunya. Hal ini dapat dimaklumi karena, usia mereka merupakan usia aktif. Sehingga mereka lebih banyak bergerak dan melakukan hal-hal lain agar tidak membosankan.

Oleh karena itu, guru menyadari bahwa metode konvensional tidak mampu memenuhi hal tersebut, sehingga perlu diberikan solusi lain yaitu menerapkan metode pengajaran yang mampu membuat siswa sibuk melakukan banyak aktivitas. Salah satu metode tersebut adalah belajar penemuan, atau yang dikenal dengan metode inkuiri. Berdasarkan hasil penelitian Wati (2016) bahwa dengan penerapan 
metode inkuiri pada pembelajaran IPA siswa lebih aktif dalam belajar. Hasil belajar siswa yang diperoleh pada siklus I adalah 45,4\%, sedangkan pada siklus II hasil belajar siswa mengalami peningkatan yaitu $86,3 \%$. Hasil observasi aktivitas siswa selama proses pembelajaran pada siklus I masih ada beberapa aspek yang belum mencapai kriteria aktif dengan skor 49 dan rata-rata 2,45 dengan kategori kurang baik sedangkan pada siklus II siswa sudah lebih aktif dengan skor yang diperoleh 70 dan rata-rata 3,50 dengan kategori sangat baik.

Piaget dalam Mulyasa (2011) menjelaskan bahwa metode inkuiri merupakan metode yang dipersiapkan agar siswa dapat melakukan eksperimen secara mandiri, yaitu dengan memperhatikan dan mengamati kejadian alam di sekitar, selanjutnya diharapkan siswa mampu untuk menarik kesimpulan dari hasil pengamatan yang dilakukan, serta antar siswa mampu mendiskusikan dan membandingkanhasil pengamatan yang ditemukan. Oleh karena itu diharapkan dengan penerapan metode inkuiri hasil belajar siswa akan meningkat, ini dikarenakan metode inkuiri merupakan metode yang mempersiapkan siswa agar dapat merasakan langsung kejadian yang dipelajarinya dengan eksperimen, serta siswa dapat menemukan jawaban pertanyaan yang ingin diketahuinya dengan eksperimen yang telah dilakukannya.

\section{B. Metode}

Penelitian ini menggunakan metode penelitian eksperimen semu (quasi experimental design) dengan menggunakan kelompok eksperimen dan kelompok control. Desain penelitian yang digunakan adalah Desain control group postest design (Sari, 2017). Populasi merupakan keseluruhan objek yang akan diteliti. Dalam penelitian ini yang menjadi populasi adalah seluruh kelas IV siswa MIS Gampong Mutia yang keseluruhannya berjumlah 210 orang.

Pengambilan sampel dalam penelitian ini menggunakan metode secara random (Sugiyono, 2012). Pemilihan sampel secara random dikarenakan populasi pada kelas IV MIS Gampong Mutia memiliki karakteristik homogen yang terdiri dari tiga kelas. Adapun yang menjadi sampel dalam penelitian ini adalah 2 kelas yang terbagi dari kelas kontrol dan kelas eksperimen. Data yang diperoleh selanjutnya dianalisis menggunakan uji t menurut Sudjana (2016) dengan rumus sebagai berikut: 


\section{Hasil dan Pembahasan}

Keseluruhan rangkaian pelaksanaan pengumpulan data penelitian penerapan metode inkuiri dalam pembelajaran IPA pada materi struktur dan fungsi bagian tumbuhan di kelas IV MIS Gampong Mutia, telah diperoleh data penelitian.

\section{Hasil Analisis Kelas Eksperimen}

Tabel 1 Data Nilai pretest dan Posttes Kelas Eksperimen

\begin{tabular}{cccc}
\hline Pretest & Frekuensi & Posttest & Frekuensi \\
\hline 60 & 3 & 60 & 1 \\
70 & 8 & 70 & 5 \\
80 & 5 & 80 & 10 \\
90 & 1 & 90 & 1 \\
100 & 3 & 100 & 3 \\
\hline
\end{tabular}

Berdasarkan tabel 1 terlihat bahwa ada peningkatan frekuensi nilai yang diperoleh siswa sebelum dan setelah perlakuan. Nilai terendah (pretest) yang diperoleh adalah 60 yaitu sebanyak 3 orang siswa, nilai terbanyak adalah 70 yang diperoleh oleh 8 orang, sementara tertinggi 100 diperoleh 3 orang siswa. Namun setelah perlakuan (postest), nilai terendah (pretest) yang diperoleh adalah 60 hanya 1 orang, nilai terbanyak adalah 80 yang diperoleh oleh 10 orang, sementara tertinggi 100 diraih oleh 3 orang siswa.

\section{Hasil Analisis Kelas Eksperimen}

Tabel 2 Data Nilai Pretest dan Posttest Kelas Kontrol

\begin{tabular}{cccc}
\hline Nilai Pretest & Frekuensi & $\begin{array}{c}\text { Nilai } \\
\text { Posttest }\end{array}$ & \\
\hline 60 & 5 & 60 & 4 \\
70 & 7 & 70 & 8 \\
80 & 6 & 80 & 5 \\
90 & 1 & 90 & 2 \\
100 & 1 & 100 & 1 \\
\hline
\end{tabular}

Berdasarkan tabel 2 terlihat bahwa ada peningkatan frekuensi nilai yang diperoleh siswa pada kelas kontrol. Nilai terendah (pretest) yang diperoleh adalah 60 yaitu sebanyak 5 orang siswa, nilai terbanyak adalah 70 yang diperoleh oleh 7 orang, sementara tertinggi 100 diperoleh 1 orang siswa. Namun setelah dilakukan tes akhir (postest), nilai terendah yang diperoleh adalah 60 sebanyak 4 orang, nilai terbanyak adalah 70 yang diperoleh oleh 8 orang, sementara tertinggi 100 hanya diraih oleh 1 orang siswa. 


\section{Pengujian Hipotesis}

Berdasarkan uji perbandingan nilai postest dengan menggunakan uji t, maka diperoleh nilai $t_{\text {hitung }}=5.59$ dengan nilai $t_{\text {tabel }}=2.02$, artinya $t_{\text {hitung }}>t_{\text {tabel }}(5.59>2.02)$ oleh karenanya $\mathrm{H}_{0}$ ditolak dan $\mathrm{H}_{\mathrm{a}}$ diterima, dapat disimpulkan bahwa ada peningkatan hasil belajar IPA siswa setelah diterapkan metode inkuiri pada materi struktur dan fungsi bagian tumbuhan.

\section{Pembahasan}

Prestasi belajar merupakan parameter yang dapat dijadikan tolok ukur keberhasilan siswa dalam belajar. Hal ini menjadi acuan utama dalam pelaksanaan proses belajar mengajar. Sudjana (2011), mengemukakan bahwa belajar adalah suatu proses yang ditandai dengan adanya perubahan dari diri seseorang. Perubahan ini dapat ditunjukkan dalam berbagai bentuk seperti adanya perubahan pengetahuan, pemahaman, sikap serta tingkah laku, keterampilan, kecakapan, kebiasaan, dan perubahan pada aspek lainnya. Sari \& Rizki (2017) juga menjelaskan bahwa pemilihan metode yang tepat dan melibatkan aktivitas belajar siswa secara otomatis dapat meningkatkan hasil belajarnya.

Jadi dengan melewati proses belajar mengajar diharapkan adanya perubahan-perubahan yang bernilai positif dalam diri siswa. Lebih terperinci perubahan ini dapat ditunjukkan secara signifikan melalui prestasi belajar siswa dalam bentuk nilai-nilai tertentu. Dalam rangka mendukung tercapainya pembelajaran yang optimal, maka sudah menjadi tanggung jawab pihak sekolah untuk mengimplementasikan program unggulan yang dapat membantu peningkatan hasil belajar siswa. Hal ini dapat dimulai dari penerapan metode-metode belajar mengajar di kelas yang dapat merangsang dan melatih kemampuan siswa untuk lebih aktif, kreatif serta inovatif.

\section{E. Kesimpulan}

Metode inkuiri dinilai efektif meningkatkan keberhasilan dalam mempelajari mata pelajaran IPA materi struktur dan fungsi bagian tumbuhan. Informasi hasil pengajaran dengan metode inkuiri siswa MIS Gampong Meutia mampu memberikan pendapat dan berdiskusi secara aktif. 


\section{Daftar Pustaka}

Fitriani, I. (2010). Penggunaan Multi Media Interaktif Dalam Proses Pembelajaran Materi Teori Kinetic Gas Untuk Meningkatkan Pemahaman Konsep Dan Keterampilan Berpikir Kreatif Siswa SMA. Sekolah Pascasarjana Universitas Pendidikan Indonesi Bandung.

Mulyasa, E. (2011). Menjadi Guru Profesional Menciptakan Pembelajaran Kreatif dan Menyenangkan. Bandung: Remaja Rosdakarya.

Sari, R. (2017). Pengantar Penelitian Kuantitatif (1st ed.). Yogyakarta: Deepublish.

Sari, R., \& Rizki, S. (2017). Think pair share : Alternatif peningkatan aktivitas dan hasil belajar IPA. PeTeKa (Jurnal Penelitian Tindakan Kelas Dan Pengembangan Pembelajaran), 1(1), 41-47. Retrieved from http://jurnal.umtapsel.ac.id/index.php/ptk/article/view/310

Sudjana. (2016). Metoda Statistika (7th Edition). Metoda Statistika.

Sudjana, N. (2011). Pedoman Praktis Mengajar. Bandung: Dermaga.

Sugiyono. (2012). Metode Penelitian Kuantitatif, Kualitatif dan R \& D.Bandung:Alfabeta. Metode Penelitian Kuantitatif, Kualitatif Dan $R$ \& D.Bandung:Alfabeta. https://doi.org/10.1017/CB09781107415324.004

Wati, M. (2016). Penerapan Metode Inkuiri dalam Meningkatkan Hasil Belajar IPA Siswa Kelas III MIN Bukit Baro II Indrapuri Aceh Besar. Fakultas Tarbiyah dan Keguruan Universitas Islam Negeri Ar-Raniry Darussalam-Banda Aceh. 